\title{
Analysis and Design of High Step-Up DC-DC Converter for Photovoltaic Application
}

\author{
D.Saravanan ${ }^{1}$, C.Govindaraju ${ }^{2}$ \\ ${ }^{I} P G$ scholar (PED), Dept of EEE, Government college of Engineering, Salem, India \\ ${ }^{2}$ Assistant Professor, Dept of EEE, Government college of Engineering, Salem, India
}

\begin{abstract}
Now a day's Photovoltaic power generation is essential for the developing countries to meet their electricity demand. The power generated from the (PV) module has been connected to the panel through the proper channel of DC-DC converter and DC-AC inverter. This paper proposes a new high step up DC-DC converter with floating active switch which acts as a high state drive. This floating active switch isolates energy from the PV panel when the ac module is off. It also regulates the DC interface between the DC-AC converters. The high step up voltage conversion ratio is achieved with numerous turns ratio of a coupled inductor and appropriate duty ratios. The energy stored in the leakage inductor with the help of magnetizing inductor of a coupled inductor is efficiently recycled to the load through the output capacitor. With an input voltage of (Vin) $15 \mathrm{~V}$ and $250 \mathrm{~V}$ output voltage is obtained. An output power of $97 \mathrm{~W}$ is also obtained from the designed converter circuit. Its maximum full load efficiency is better than conventional convert model.
\end{abstract}

Keywords-AC Module, floating active switch, coupled inductor, high step up Voltage conversion ratio.

\section{Introduction}

Non-conventional energy is becoming increasingly important and prevalent in distribution systems. The uses of alternative sources of energy like fuel and solar requires a large step up conversion of their low voltage level to the required level of voltage. A PV array is a serial connection of numerous panels to obtain a higher DC-link voltage.

This dc voltage can be utilized for the main electricity through the DC-AC inverter [1],[30]. An ac module is a micro inverter configured on the rear bezel of PV panel, this will immunizes against the yield loss by shadow effect. The prior works have proposed the converter with single switch and fewer components to fit the dimensions of the bezel of the ac module, but their efficiency levels are low. The power capacity range of $50 \mathrm{~W}$ to $250 \mathrm{~W}$ and the maximum power point voltage range is $12 \mathrm{~V}$ to $40 \mathrm{~V}$ which will give as input.

In case if the voltage derived from the PV panel is lower, then it is difficult for the ac module to reach the high efficiency. However employing a high step-up DC-DC converter in front of the inverter, which improves the power conversion efficiency from one level to another level and it also provides the stable DC link to the inverter.

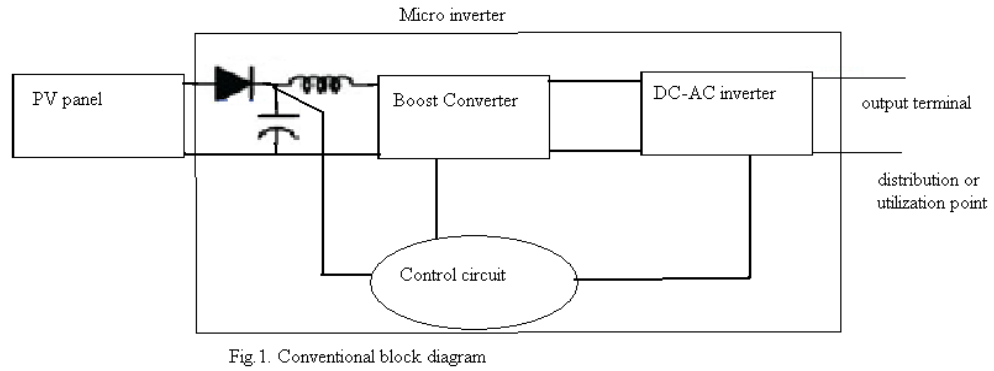

During the installation of PV panel generation system during day light, for safety reason the AC module outputs zero voltage [4], [5]. While installing the ac module, the potential difference could pose hazards to both the worker and the facilities. A floating active switch is designed to isolate the DC from the PV panel, for when the AC module is off grid as well as non operating condition. This isolation ensures the operation of the internal components without any residential energy being transferred to the terminals, which could be unsafe. Use of active clamp technique not only recycles the leakage inductor energy but also it constraints the voltage stress across the switch. This means the coupled inductor employed in voltage liter or voltage multiplier technique in a circuit.

The DC-DC converter requires a large step-up voltage conversion from low voltage obtained from the panel low voltage to the required voltage level for the application. In the previous research on various converters for high step-up applications has included analyses of the switched - capacitor type [6], [7], [8], [9], [29]; the voltage-lift type [12]; the capacitor-diode voltage multiplier [13]; and the boost type integrated with coupled inductor [10], [11], these converters by increasing turns ratio of coupled inductor obtain higher voltage gain than 
conventional boost converter. Some converters successfully combined boost and flyback converters, some converters, since various converter combinations are developed to carryout high step up voltage gain by using the coupled-inductor technique [14]-[19], [27], [28]. The efficiency and voltage gain of the DC-DC boost converter are constrained by either switches or the reverse recovery issues of the diodes.

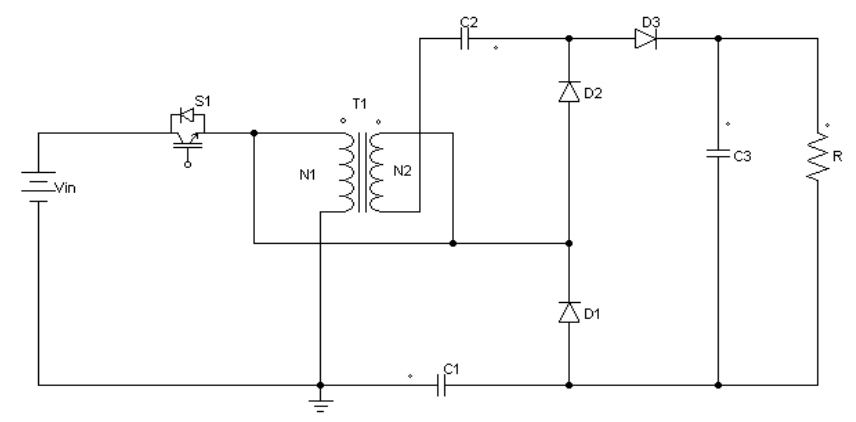

Fig.2. Circuit configuration of proposed converter

The proposed converter is shown in figure.2. It consists of coupled inductor $\mathrm{T}_{1}$ with floating active switch $S_{1}$. The primary winding $\mathrm{N}_{1}$ of a coupled inductor $\mathrm{T}_{1}$ is similar to the input inductor of the conventional boost converter and capacitor $C_{1}$ and diode $D_{1}$ receive leakage inductor energy from $N_{1}$. The secondary winding $\mathrm{N}_{2}$ of Coupled inductor $\mathrm{T}_{1}$ is connected with another pair of capacitor $\mathrm{C}_{2}$ and diode $\mathrm{D}_{2}$, which are in series with $\mathrm{N}_{1}$ in order to further enlarge the boost voltage. The diode $\mathrm{D}_{3}$ is a diode rectifier which is connected to the output capacitor $\mathrm{C}_{3}$ and load.

\section{Operating Principles Of The Proposed Converter}

In order to analysis the circuit of the proposed converter, the following assumptions are made.

1) All the components are ideal expect for the leakage inductance of coupled inductor $T_{1}$.

2) The on-state resistance $R_{D S(o n)}$ and all the snubber capacitance of $S_{1}$ are neglected.

3) The capacitors $C 1^{\sim} C 3$ are sufficiently large that the voltages across them are considered to be constant.

4) The ESR of capacitors $C 1 \sim C 3$ and the parasitic resistance of coupled inductor $T 1$ are neglected.

5) The turn ratio $n$ of the coupled inductor $T 1$ windings is equal to $N 2 / N 1$.

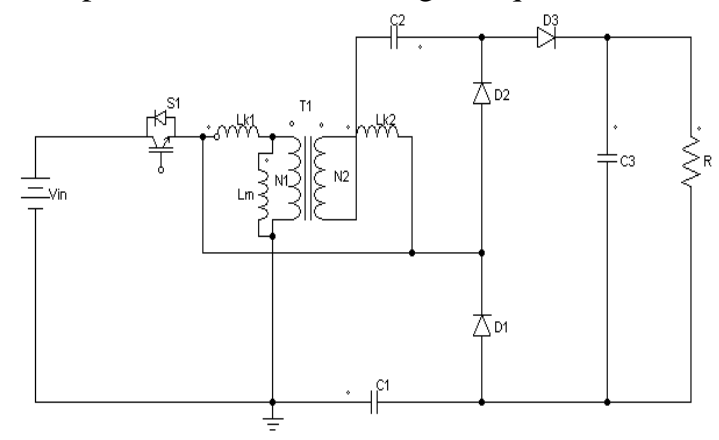

Fig.3. Polarity definitions of voltage and current in proposed converter.

The designed converter can be worked in two modes of operation, they are

i) Continuous conduction mode

ii) Discontinuous conduction mode.

iii)

\subsection{Continuous Conduction Mode Operation (CCM)}

In the continuous conduction mode there are many transition intervals will takes place. Initially whenever the supply is applied and made the switch $S_{1}$ to turned $O N$, then the magnetizing inductor $L_{m}$ continuously charges capacitor $\mathrm{C}_{2}$ through coupled inductor $\mathrm{T}_{1}$. The current $\mathrm{i}_{\mathrm{Lm}}$ is continuously decreases because the source voltage $\mathrm{V}_{\text {in }}$ crosses the magnetizing inductor $\mathrm{L}_{\mathrm{m}}$ and primary leakage inductor $\mathrm{L}_{\mathrm{k} 1}$ during this time the $i_{D 2}$ and $i_{c 2}$ are decreasing. Once the leakage current equals the decreasing $i_{L m}$, then the $V_{\text {in }}$ is series connected with $\mathrm{N}_{2}, \mathrm{C}_{1}$ and $\mathrm{C}_{2}$ to charges the output capacitor $\mathrm{C}_{3}$ and load $\mathrm{R}$. The rectifier diode $\mathrm{D}_{3}$ is conducting but diode $\mathrm{D}_{2}$ will not conduct. The $\mathrm{i}_{\mathrm{Lm}}, \mathrm{i}_{\mathrm{Lk} 1}$, and $\mathrm{i}_{\mathrm{d} 3}$ are increasing because the $\mathrm{V}_{\mathrm{in}}$ is crossing $\mathrm{L}_{\mathrm{k} 1}, \mathrm{~L}_{\mathrm{m}}$ and primary winding $\mathrm{N}_{1}$. The discharging current $\left|\mathrm{i}_{\mathrm{cl}}\right|$ and $\left|\mathrm{i}_{\mathrm{c} 2}\right|$ are increasing.

When the switch $S_{1}$ is made off, instantly the energy stored in the inductor $L_{k 1}$ will flows through the diode $\mathrm{D}_{1}$ to charge the capacitor $\mathrm{C}_{1}$ meanwhile the energy stored in the leakage inductor $\mathrm{L}_{\mathrm{k} 2}$ is series connected with $C_{2}$ to charge the capacitor $C_{3}$ and the load $R . L_{k 1}$ and $L_{k 2}$ are far smaller than $L_{m}$ due to this the $i_{L m}$ is increasing with energy receiving from $i_{\mathrm{Lk} 1}$ and $\mathrm{i}_{\mathrm{Lk} 2}$ decreases rapidly to zero. Once $\mathrm{i}_{\mathrm{Lk} 2}$ reaches the zero, the $\mathrm{L}_{\mathrm{m}}$ 
released its energy to $C_{1}$ and $C_{2}$. Simultaneously diodes $D_{1}$ and $D_{2}$ are conducting. The energy stored in the capacitor $\mathrm{C}_{3}$ is constantly discharged to the load $\mathrm{R}$. This process will continue for each turn on and turn off Switch $\mathrm{S}_{1}$

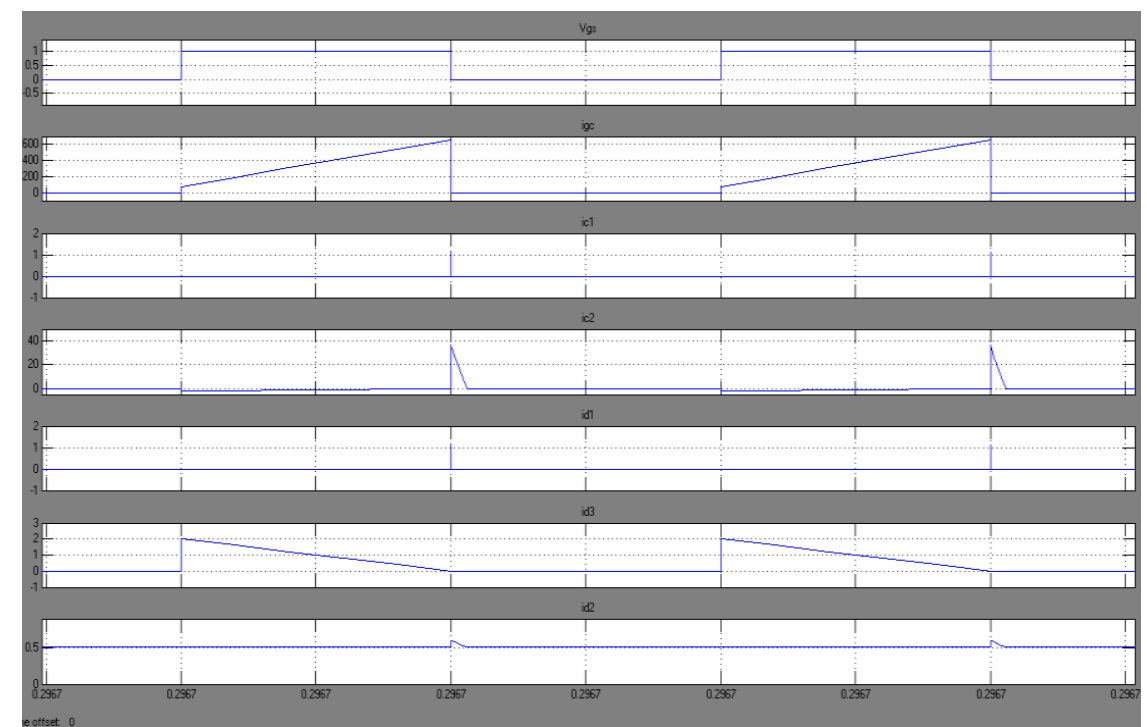

Fig.4. current wave forms of proposed converter at CCM

\subsection{Dis-Continuous Conduction Mode Operation}

In the discontinuous mode there are many transition intervals will takes place. Initially when the switch $S_{1}$ is made ON with input source $V_{\text {in. }}$. The inV0put source $V_{\text {in }}$ is series connected with $N_{2}, C_{1}$ and $C_{2}$ to charge the output capacitor $C_{3}$ and load $R$. Meanwhile $L_{m}$ is also receiving energy from $V_{\text {in }}$. The $i_{L m}, i_{L k 1}$ and $i_{D 3}$ are increasing because the $\mathrm{V}_{\mathrm{in}}$ is increasing $\mathrm{L}_{\mathrm{k} 1}, \mathrm{~L}_{\mathrm{m}}$ and primary winding $\mathrm{N}_{1}$. The discharging current $\left|\mathrm{i}_{\mathrm{c} 1}\right|$ and $\left|\mathrm{i}_{\mathrm{c} 2}\right|$ are increasing.

When the switch $S_{2}$ made off then instantly the energy stored in the leakage inductor $L_{k 1}$ flows through diode $\mathrm{D}_{1}$ to charge the capacitor $\mathrm{C}_{1} .\left|\mathrm{i}_{\mathrm{c} 1}\right|$ and $\left|\mathrm{i}_{\mathrm{c} 2}\right|$ increases and current through $\mathrm{i}_{\mathrm{D} 3}$ also increase. Then the current $i_{1 k 1}$ and $i_{D 1}$ are continuously decreased because the leakage energy flows through $D_{1}$ keeps charging a capacitor $\mathrm{C}_{1}$. The energy stored in capacitor $\mathrm{C}_{3}$ is constantly discharged to the load $\mathrm{R}$. These energy transfers results in decrease in $i_{L k 1}$ and $i_{L m}$ but increases in $i_{L k 2}$. $L_{m}$ only constantly releasing its energy to $C_{2}$ and only Diode $D_{2}$ is conducting. The $i_{\mathrm{Lm}}$ is decreasing due to the magnetizing inductor energy flowing through the coupled inductor $T_{1}$ to secondary winding $\mathrm{N}_{2}$ and $\mathrm{D}_{2}$ continuous to charge capacitor $\mathrm{C}_{2}$. The energy stored in capacitor $\mathrm{C}_{2}$ is continued to be discharge to the load. This process will continue for each turn on and turn off Switch $\mathrm{S}_{1}$.

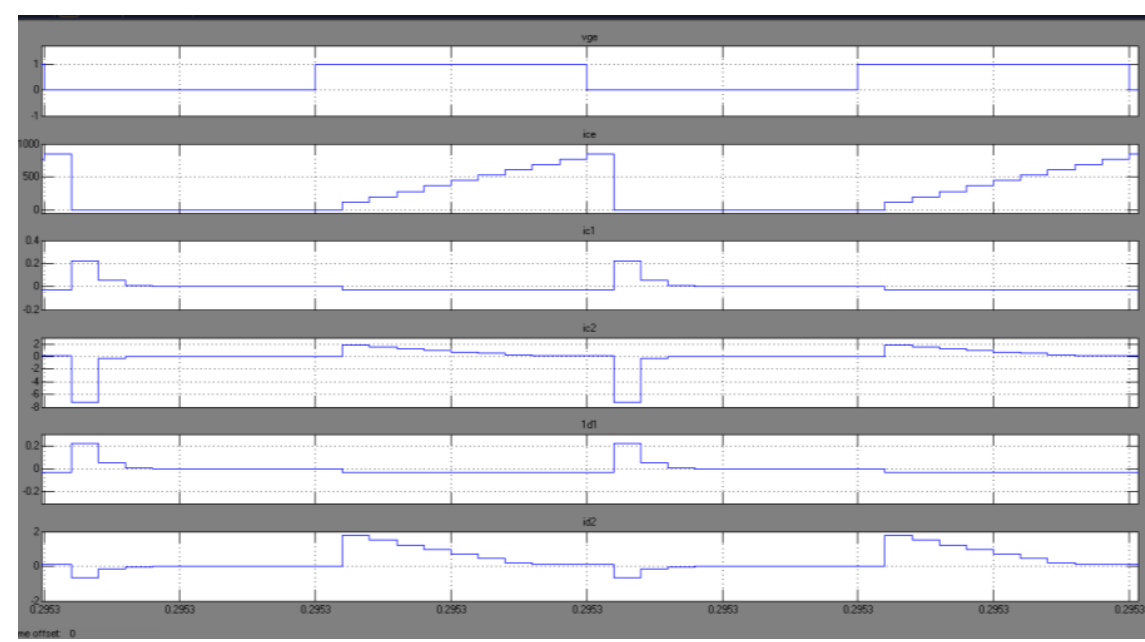

Fig.5. current waveforms of proposed converter at DCM

\section{Analysis Of Proposed Converter}




\subsection{CCM Operation}

instants.

For the steady state analysis of converter the two switching instants are considered, $\mathrm{S}_{1} \mathrm{ON}$ and OFF

During $\mathrm{S}_{1} \mathrm{ON}$

$$
\begin{aligned}
& \mathrm{V}_{\mathrm{Lm}}=\mathrm{V}_{\text {in }} \\
& \mathrm{V}_{\mathrm{N} 2}=\mathrm{nV} \mathrm{V}_{\text {in }}
\end{aligned}
$$

During $\mathrm{S}_{1} \mathrm{OFF}$

$$
\begin{aligned}
& V_{\mathrm{Lm}}=-\mathrm{V}_{\mathrm{c} 1} \\
& \mathrm{~V}_{\mathrm{N} 2}=-\mathrm{V}_{\mathrm{c} 2} .
\end{aligned}
$$

The voltage across $\mathrm{C}_{1}$ and $\mathrm{C}_{2}$ are obtained as

$$
\begin{aligned}
& \mathrm{V}_{\mathrm{cl}}=(D \mid 1-D) \mathrm{V}_{\text {in }} \\
& \mathrm{V}_{\mathrm{c} 2}=(n D \mid 1-D) \mathrm{V}_{\text {in }}
\end{aligned}
$$

The output voltage of the converter during switch $\mathrm{S}_{1}$ on is given by

$$
\begin{aligned}
& \mathrm{V}_{0}=\mathrm{V}_{\text {in }}+\mathrm{V}_{\mathrm{N} 2}+\mathrm{V}_{\mathrm{C} 2}+\mathrm{V}_{\mathrm{Cl}} ; \\
& \mathrm{V}_{0}=\mathrm{V}_{\text {in }}+\mathrm{nV}_{\text {in }}+(n D \mid 1-D) \mathrm{V}_{\text {in }}+(D \mid 1-D) \mathrm{V}_{\text {in }} \\
& \mathrm{MCCM}=\mathrm{V}_{0} / \mathrm{V}_{\text {in }}(1+n \mid 1-D)
\end{aligned}
$$

\subsection{DCM Operation} instants.

For the steady state analysis of the converter at two switching instants are considered, $\mathrm{S}_{1} \mathrm{ON}$ and OFF

During $\mathrm{S}_{1} \mathrm{ON}$

$$
\begin{aligned}
& \mathrm{V}_{\mathrm{Lm}}=\mathrm{V}_{\text {in }} \\
& \mathrm{V}_{\mathrm{N} 2}=\mathrm{nV}_{\text {in }}
\end{aligned}
$$

During $\mathrm{S}_{1} \mathrm{OFF}$

$$
\begin{aligned}
& V_{\mathrm{Lm}}=-\mathrm{V}_{\mathrm{c} 1} \\
& -\mathrm{V}_{\mathrm{N} 2}=\mathrm{V}_{\mathrm{c} 2}
\end{aligned}
$$

The voltage across $\mathrm{C}_{1}$ and $\mathrm{C}_{2}$ are

$\mathrm{V}_{\mathrm{cl}}=(D \mid D L) \mathrm{V}_{\text {in }}$

$\mathrm{V}_{\mathrm{c} 2=}(n D \mid D L) \mathrm{V}_{\text {in }}$

$($ V0|vin $)=((n+1) \mid(D+D L)) / \mathrm{D}_{\mathrm{L}}$

\section{Simulation Results}

The designed high step-up DC-DC converter consists of single active switch, which acts as high state drive. It also contains the coupled inductor, 2diodes and 2capacitors used to step-up the voltage level and it also recycles the leakage energy. One diode is used as rectifier diode.

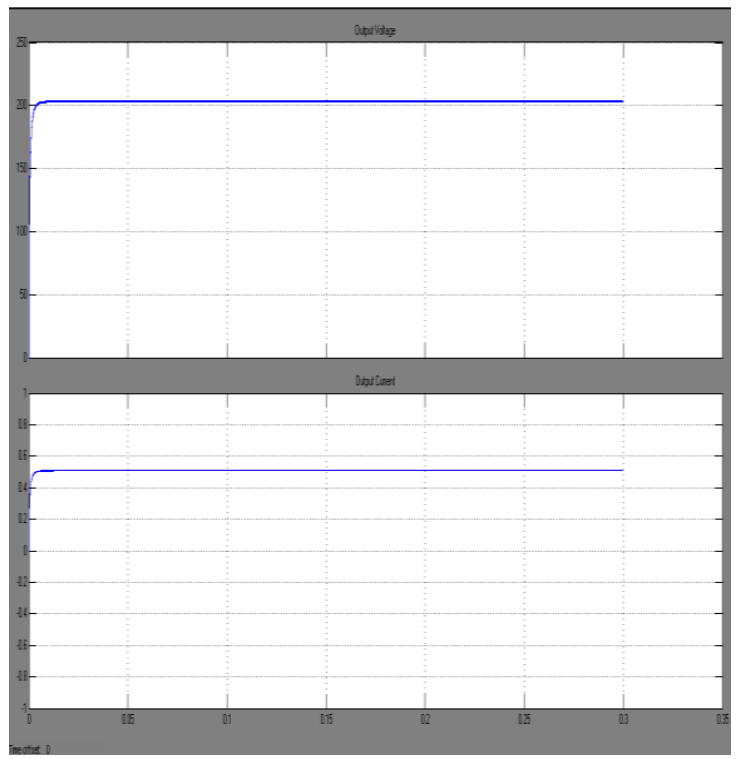

Fig.6. output voltage and current waveform at CCM

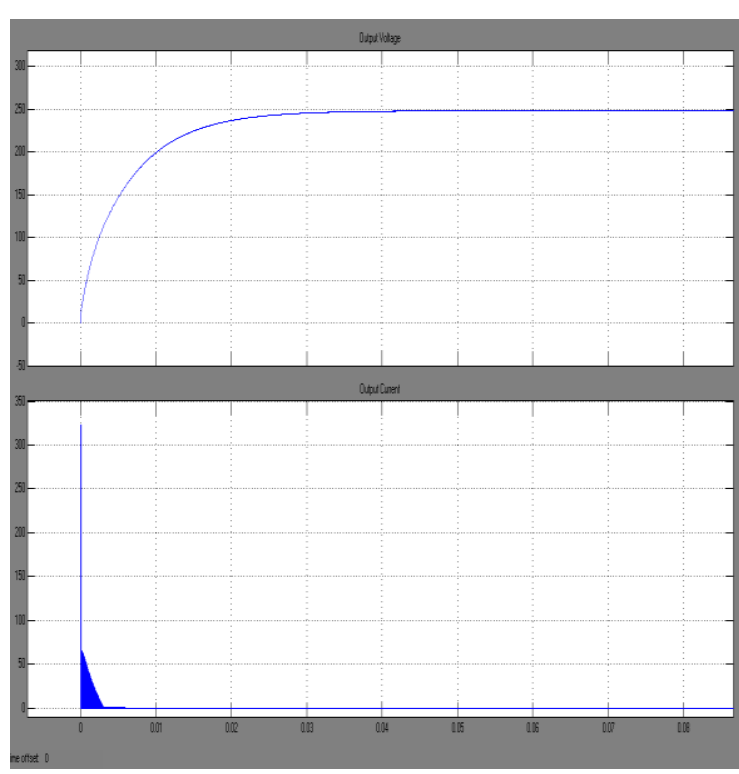

Fig.7. output voltage and current waveform at DCM 


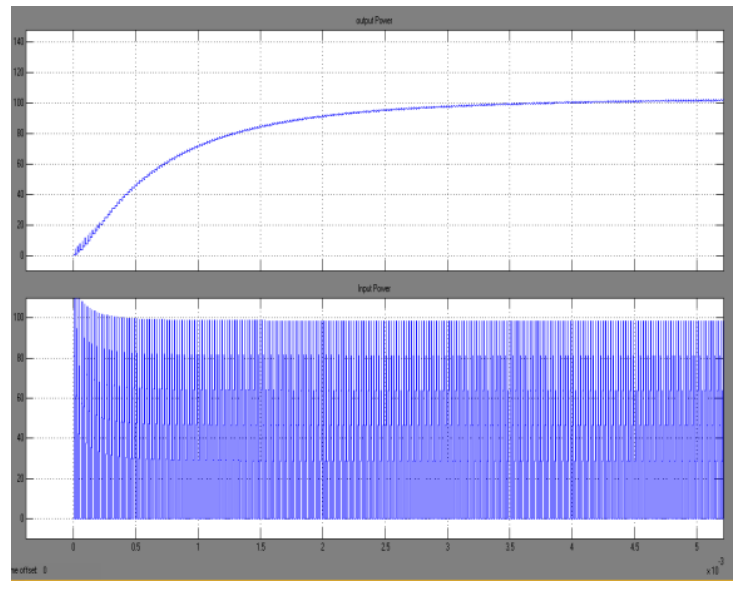

Fig.8. output and input power of proposed converter

\begin{tabular}{|c|c|c|c|}
\hline MODE & Parameter & Input & Output \\
\hline \multirow{4}{*}{ CCM } & Voltage(peak to peak) & $15 \mathrm{v}$ & $203 \mathrm{~V}$ \\
\cline { 2 - 4 } & & & \\
\cline { 2 - 4 } & Current(Peak to Peak) & $6.5 \mathrm{~A}$ & $0.5 \mathrm{~A}$ \\
\cline { 2 - 4 } & Power(Peak to Peak) & $99 \mathrm{~W}$ & $97 \mathrm{~W}$ \\
\hline \multirow{2}{*}{ DCM } & Voltage(peak to peak) & $15 \mathrm{~V}$ & $250 \mathrm{~V}$ \\
& & & \\
\cline { 2 - 4 } & Current(Peak to Peak) & $1.5 \mathrm{~A}$ & $0.5 \mathrm{~A}$ \\
\hline
\end{tabular}

Table.1. Input and output from simulation

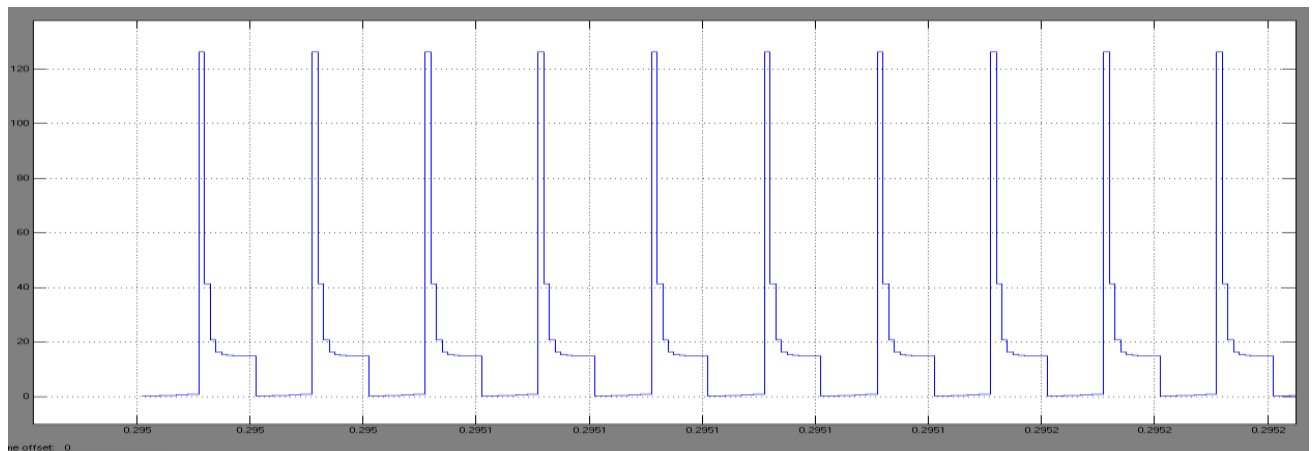

Fig.9.Voltage stress across the switch

These are the various results obtained from the proposed converter with the electrical specifications of the circuit components with an applied voltage $\mathrm{V}_{\text {in }}=15 \mathrm{~V}, \mathrm{f}_{\mathrm{s}}=50 \mathrm{kHz}$, and full load resistance of $\mathrm{R}=400 \Omega$. The major components with the values of $\mathrm{C}_{1}=\mathrm{C}_{2}=47 \mu \mathrm{F}$ and $\mathrm{C}_{3}=220 \mu \mathrm{F}$, the switch used for the simulation is IGBT, for recycling and rectifying diodes are used. The turns ration of the mutual inductor is assumed to be $\mathrm{n}=5$, and the duty ratio $\mathrm{D}$ is derived as $50 \%$. The magnetizing inductor of the coupled inductor $\mathrm{L}_{\mathrm{m}}>30.54$ for the full load. The maximum full load efficiency of the proposed converter at continuous conduction mode is given by $97 \%$, this will be better than conventional converter. The proposed converter shows the wide range of efficiency.

\section{Conclusion}

The energy of leakage inductor's has been effectively recycled and the voltage stress across the switch is constrained. The switch here acts as an high state drive and also it protects panel and installers from the electrical hazardous while the switch is in off state. The switching action is performed well by floating active switch during the system operation at all the condition with eliminating the residential energy effectively during non operating condition. Without an extreme duty ratio and with an numerous turns ratio the proposed converter achieved high voltage step-up gain. Thus improvements to the efficiency of the proposed converter have achieved.

\section{References}

[1] T. Shimizu, K. Wada, and N. Nakamura, "Flyback-type single-phase utility interactive inverter with power pulsation decoupling on the dc input for an ac photovoltaic module system," IEEE Trans. Power Electron., vol. 21, no. 5, pp. 1264-1272, Jan. 2006.

[2] C. Rodriguez and G. A. J. Amaratunga, "Long-lifetime power inverter for photovoltaic ac modules," IEEE Trans. Ind. Electron., vol. 55, no. 7, pp. 2593-2601, Jul. 2008.

[3] S. B. Kjaer, J. K. Pedersen, and F. Blaabjerg, "A review of single-phase grid-connected inverters for photovoltaic modules," IEEE Trans. Ind. Appl., vol. 41, no. 5, pp. 1292-1306, Sep./Oct. 2005.

[4] J. J. Bzura, "The ac module: An overview and update on self-contained modular PV systems," in Proc. IEEE Power Eng. Soc. Gen. Meeting, Jul. 2010, pp. 1-3.

[5] B. Jablonska, A. L. Kooijman-van Dijk, H. F. Kaan, M. van Leeuwen, G. T. M. de Boer, and H. H. C. de Moor, "PV-PRIVE project at ECN, five years of experience with small-scale ac module PV systems," in Proc. 20th Eur. Photovoltaic Solar Energy Conf., Barcelona, Spain, Jun. 2005,pp. 2728-2731

[6] T. Umeno, K. Takahashi, F. Ueno, T. Inoue, and I. Oota, "A new approach to low ripple-noise switching converters on the basis of switched- capacitor converters," in Proc. IEEE Int. Symp. Circuits Syst., Jun. 1991, pp. 1077- 1080.

[7] B. Axelrod, Y. Berkovich, and A. Ioinovici, "Switched- capacitor/ switched-inductor structures for getting transformerless hybrid 
dc-dc PWM converters," IEEE Trans. Circuits Syst. I, Reg. Papers, vol. 55, no. 2, pp. 687-696, Mar. 2008.

[8] B. Axelrod, Y. Berkovich, and A. Ioinovici, "Transformerless dc-dc con-verters with a very high dc line-to-load voltage ratio," in Proc. IEEE Int. Symp. Circuits Syst. (ISCAS), 2003, vol. 3, pp. 435-438.

[9] H. Chung and Y. K. Mok, "Development of a switched-capacitor dc-dc boost converter with continuous input current waveform," IEEE Trans. Circuits Syst. I, Fundam. Theory Appl., vol. 46, no. 6, pp. 756-759, Jun. 1999.

[10] T. J. Liang and K. C. Tseng, “Analysis of integrated boost-flyback step-up converter," IEE Proc. Electrical Power Appl., vol. 152, no. 2, pp. 217-225, Mar. 2005.

[11] Q. Zhao and F. C. Lee, "High-efficiency, high step-up dc-dc converters," IEEE Trans. Power Electron., vol. 18, no. 1, pp. 65-73, Jan. 2003.

[12] M. Zhu and F. L. Luo, "Voltage-lift-type cuk converters: Topology and analysis," IET Power Electron., vol. 2, no. 2, pp. 178-191, Mar. 2009.

[13] J. W. Baek, M. H. Ryoo, T. J. Kim, D. W. Yoo, and J. S. Kim, "High boost converter using voltage multiplier," in Proc. IEEE Ind. Electron. Soc. Conf. (IECON), 2005, pp. 567-572.

[14] J. Xu, "Modeling and analysis of switching dc-dc converter with coupled-inductor," in Proc. IEEE 1991 Int. Conf. Circuits Syst. (CICCAS), 1991, 717-720.

[15] R. J. Wai, C. Y. Lin, R. Y. Duan, and Y. R. Chang, "High-efficiency dc-dc converter with high voltage gain and reduced switch stress," IEEE Trans. Ind. Electron., vol. 54, no. 1, pp. 354-364, Feb. 2007.

[16] S. M. Chen, T. J. Liang, L. S. Yang, and J. F. Chen, "A cascaded high step-up dc-dc converter with single switch for microsource applications," IEEE Trans. Power Electron., vol. 26, no. 4, pp. 1146-1153, Apr. 2011.

[17] T. J. Liang, S. M. Chen, L. S. Yang, J. F. Chen, and A. Ioinovici, "Ultra large gain step-up switched-capacitor dc-dc converter with coupled inductor for alternative sources of energy," IEEE Trans. Circuits Syst. I, to be published.

[18] L. S. Yang and T. J. Liang, "Analysis and implementation of a novel bidirectional dc-dc converter," IEEE Trans. Ind. Electron., vol. 59, no. 1, 422-434, Jan. 2012.

[19] W. Li and X. He, "Review of non-isolated high-step-up dc/dc converters in photovoltaic grid-connected applications," IEEE Trans. Ind. Electron., vol. 58, no. 4, pp. 1239-1250, Apr. 2011.

[20] S. H. Park, S. R. Park, J. S. Yu, Y. C. Jung, and C. Y. Won, “Analysis and design of a soft-switching boost converter with an HIBridge auxiliary resonant circuit," IEEE Trans. Power Electron., vol. 25, no. 8, pp. 2142- 2149, Aug. 2010.

[21] G. Yao, A. Chen, and X. He, "Soft switching circuit for interleaved boost converters," IEEE Trans. Power Electron., vol. 22, no. 1, pp. 80-86, Jan. 2007.

[22] Y. Park, S. Choi, W. Choi, and K. B. Lee, "Soft-switched interleaved boost converters for high step-up and high power applications," IEEE Trans. Power Electron., vol. 26, no. 10, pp. 2906-2914, Oct. 2011.

[23] Y. Zhao, W. Li, Y. Deng, and X. He, "Analysis, design, and experimenta-tion of an isolated ZVT boost converter with coupled inductors," IEEE Trans. Power Electron., vol. 26, no. 2, pp. 541-550, Feb. 2011.

[24] H. Mao, O. Abdel Rahman, and I. Batarseh, "Zero-voltage-switching dc- dc converters with synchronous rectifiers," IEEE Trans. Power Electron., vol. 23, no. 1, pp. 369-378, Jan. 2008.

[25] S. Dwari and L. Parsa, "An efficient high-step-up interleaved dc-dc con-verter with a common active clamp," IEEE Trans. Power Electron., vol. 26, no. 1, pp. 66-78, Jan. 2011.

[26] C. Restrepo, J. Calvente, A. Cid, A. El Aroudi, and R. Giral, "A non-inverting buck-boost dc-dc switching converter with high efficiency and wide bandwidth," IEEE Trans. Power Electron., vol. 26, no. 9, pp. 2490- 2503, Sep. 2011.

[27] K. B. Park, G. W. Moon, and M. J. Youn, "Nonisolated high step-up boost converter integrated with sepic converter," IEEE Trans. Power Electron., vol. 25, no. 9, pp. 2266-2275, Sep. 2010.

[28] L. S. Yang, T. J. Liang, and J. F. Chen, "Transformerless dc-dc converters with high step-up voltage gain," IEEE Trans. Ind. Electron., vol. 56, no. 8, PP.3144-3152, Aug. 2009.

[29] N. Pogaku, M. Prodanovic, and T. C. Green, "Modeling, analysis and testing of autonomous operation of an inverter-based microgrid," IEEE Trans. Power Electron., vol. 22, no. 2, pp. 613-625, Mar. 2007.

D.Saravanan presently pursuing his M.E degree in Power Electronics and Drives at Government College of Engineering, salem, Tamil Nadu. His area of interest is Power Electronic Converters.

Dr.C.Govindaraju presently working as Assistant Professor in Department of Electrical and Electronics Engineering, Government College of Engineering, Salem, Tamil Nadu. His area of interest is Power Electronic Converters and Power Quality. 